\title{
Tuberculosis care cascade for the indigenous population in Colombia: an operational research study*
}

\author{
Jhon Edwin Polanco-Pasaje ${ }^{1}$, lader Rodríguez-Márquez¹, Kelly Yoana Tello-Hoyos², Pilar Torres- \\ Pereda ${ }^{3}$, Bertha Leonor Guzmán-Salazar², and Freddy Pérez ${ }^{4}$
}

Suggested citation Polanco-Pasaje JE, Rodríguez-Márquez I, Tello-Hoyos KY, Torres-Pereda P, Guzmán-Salazar BL, Pérez F. Tuberculosis care cascade for the indigenous population in Colombia: an operational research study. Rev Panam Salud Publica. 2021;45:e20. https://doi.org/10.26633/RPSP.2021.20

ABSTRACT Objective. Construct and evaluate the care cascade for pulmonary tuberculosis in the indigenous population of the department of Cauca (Colombia) and identify existing gaps.

Methods. Mixed-methods sequential explanatory design. In the first phase, the pulmonary tuberculosis care cascade for the indigenous population of Cauca was evaluated. Data were obtained from secondary sources and all cases diagnosed from 1 January 2016 to 31 December 2017 were included. In the second phase, semi-structured interviews were done with nine program coordinators and 11 nursing auxiliaries to explain identified gaps. Absolute and percentage values were estimated for each of the steps and gaps in the care cascade. Quantitative and qualitative results were triangulated.

Results. In 2016 and 2017, an estimated 202 patients with respiratory symptoms were expected to be positive and 106 cases of pulmonary tuberculosis were reported among the indigenous population of the department of Cauca. A gap of $47.5 \%$ was found for diagnosis, since only $52.5 \%$ of subjects were diagnosed in health services. This gap was explained by poor quality of samples and flawed smear techniques; flaws in correct identification of patients with respiratory symptoms; limited access to diagnostic methods, such as culture and molecular tests; and limited training and high turnover of personnel in health service provider institutions.

Conclusions. The tuberculosis control program should focus actions on bridging the gap in case detection in the indigenous population.

Keywords Tuberculosis; indigenous population; health services, indigenous; health care quality, access, and evaluation; Colombia.

Tuberculosis (TB) is the world's leading cause of death by infection, affecting an estimated 10 million people in 2018 (1). The greatest burden of disease is in vulnerable populations, including indigenous peoples. There are approximately 370 million indigenous people worldwide, representing less than $5 \%$ of the world's population; however, the current burden and status of TB in indigenous peoples is not precisely known $(2,3)$.
Latin America has a high TB burden, with as many as 1,000 cases per 100,000 indigenous people, particularly in communities in the Brazilian Amazon (3-5).

The high burden of TB in certain populations can be explained by structural and proximal social determinants. A recent systematic review reported that psychoactive substance use, food insecurity, and tobacco use were the main proximal social

\footnotetext{
Official English translation from the original Spanish manuscript made by the Pan American Health Organization. In case of discrepancy, the original version shall prevail. Access to original manuscript: https://doi.org/10.26633/ RPSP.2020.150

1 Grupo de Investigación Epidemiología, Facultad Nacional de Salud Pública, Universidad de Antioquia, Medellín, Colombia. $\triangle$ Jhon Edwin Polanco-Pasaje, jhon.polanco@udea.edu.co
}

\footnotetext{
2 Secretaría de Salud Departamental, Gobernación del Cauca, Colombia.

3 Instituto Nacional de Salud Pública, Cuernavaca, Mexico.

4 Department of Communicable Diseases and Environmental Determinants of Health, Pan American Health Organization, Washington D.C., United States of America.
} 
determinants contributing to TB in indigenous populations (2). In Latin America and the Caribbean, human immunodeficiency virus (HIV) co-infection and multidrug-resistant TB are the two most important health-related factors that increase mortality in indigenous populations. In addition, improved sanitation and access to safe drinking water (both environmental determinants) make it possible to reduce TB morbidity in the Region (6).

In Colombia, 14,480 TB cases were reported in $2017,5.4 \%$ of them in indigenous people. The national incidence rate was 26.3 cases per 100,000 inhabitants (7). In the department of Cauca, TB incidence in 2017 was 17.5 cases per 100,000 inhabitants and $32 \%$ of diagnosed cases were concentrated in indigenous people. In addition, only $19.3 \%$ of new cases were confirmed by bacteriology (8). This figure is far from the target of detecting more than $90 \%$ of TB cases (9).

However, there is a lack of information on disease control measures and the gaps in TB care delivery, making it difficult to refocus interventions aimed at patients belonging to the department's indigenous groups. The treatment cascade is a tool with sequential steps and gaps in the care process, making it possible to measure a program's performance in care delivery (10). This study built and evaluated a pulmonary tuberculosis (PTB) care cascade for the indigenous population of the Cauca department during 2016-2017 and identified gaps in the cascade in order to contribute evidence that helps to focus disease prevention and control programs and policies.

\section{MATERIALS AND METHODS}

The study was conducted with a mixed methodology with a sequential explanatory design (11). The first quantitative phase consisted of a descriptive design to assess the PTB care cascade in the indigenous population of Cauca. A qualitative research phase was then initiated to explain or support the findings from the first phase (12).

The study was carried out in the department of Cauca, located in the southwestern part of Colombia. Cauca is the department with the second largest indigenous population in the country: $20.5 \%$ of people in the department self-identified as indigenous in 2017 , compared with only $4 \%$ of the general population of Colombia (2018).

The first phase included a census of people belonging to any indigenous ethnic group in Cauca who were recorded as having PTB in 2016-2017. This period ensured follow-up 18 months after termination of treatment. Patients with extrapulmonary $\mathrm{TB}$ registered in the program database were excluded. In the second phase, qualitative sampling of extreme cases was conducted with health service providers (13); the municipalities with the highest and lowest incidence of PTB in the indigenous population during the study period (14) were considered. TB program coordinators and assistants in each selected institution were included.

\section{Variables and definitions}

Methodological recommendations proposed by Subbaraman R. et al. for the construction of care cascades $(15,16)$ were adopted in the first phase. The care cascade is a model that contains steps (number of people who reach a given point in the care process) and gaps (difference between steps, representing people with suboptimal results) (16).
Five steps were defined for this study: (i) expected positive respiratory symptomatics (RS) (17); (ii) patients diagnosed with PTB; (iii) patients who initiated treatment; iv) patients who completed treatment; and v) patients who completed treatment and remained alive 18 months later. Four gaps were established: (i) patients with undiagnosed PTB; (ii) patients who did not initiate treatment; (iii) patients whose treatment failed, who died, or who were lost to treatment; and (iv) patients who died within 18 months after completing treatment (Table 1). The last step was obtained by comparing patients who completed treatment with death records. The rate of sputum-smear positivity (SS+) was used to estimate the expected total number of positive RS in the population, reflecting the historical behavior observed in the Colombian population $(18,19)$.

The following operational definitions were used: (i) PTB patient; (ii) new patient; (iii) re-initiated after relapse; (iv) cured; (v) lost to follow-up; (vi) died during treatment; and (vii) not evaluated (20). For the first step in the cascade, the size of the indigenous population was calculated according to census projections; for the following steps, it was calculated based on self-identification as indigenous (according to the records of the TB control program).

Semi-structured interviews were conducted in the second phase (21). The perceptions of health workers were explored with respect to barriers to the three thematic areas of disease control identified through a literature review and the operational guidelines of the program, namely: searching for RS, case diagnosis, and follow-up of treatment. In the first thematic area, questions were aimed at identifying aspects related to contact with the health services, planning of searches, and implementation of planned strategies. The second area involved the diagnostic methods used and access to those methods. Finally, aspects related to initiation, monitoring, and follow-up of treatment were tracked in the third area.

\section{Information gathering}

Phase 1 included all cases diagnosed between January 1, 2016 and December 31, 2017. Data were obtained from secondary sources (departmental TB program database and reports from health service providers) up to December 2018. The data were validated against other official health information subsystems in Colombia. The queried databases were merged into Microsoft Excel ${ }^{\circledR}$ to facilitate analysis.

In the second phase, semi-structured interviews were conducted with nine program coordinators and 11 nursing auxiliaries from the eight selected municipalities in the sample (four with high PTB incidence and four with low incidence, including a low incidence municipality with two HSPs) (14). Possible explanations were explored for the gaps identified in the first phase. The fieldwork was conducted by trained and independent personnel of the regional TB program.

\section{Analysis of the information}

Absolute and percent values were described for different characteristics: sociodemographic (sex, age, municipality of origin, indigenous group, and coverage type), clinical (HIV co-infection, drug susceptibility testing, and identified drug resistance) and programmatic (notification period, and admission and discharge status). Absolute and percent values were estimated at 
TABLE 1. Definitions, methods, and information sources for the pulmonary tuberculosis care cascade in the indigenous population of Cauca, Colombia (2016-2017)

\begin{tabular}{|c|c|c|c|c|}
\hline Category & Steps and gaps & Operational definition & Estimation method & Information source \\
\hline \multirow[t]{2}{*}{ Access to care } & Step 1 & $\begin{array}{l}\text { Total expected number of sputum- } \\
\text { smear positive (SS+) respiratory } \\
\text { symptomatics (RS) in the } \\
\text { indigenous population of Cauca }\end{array}$ & $\begin{array}{l}\text { The expected number of SRs was } \\
\text { estimated as } 5 \% \text { of half of the indigenous } \\
\text { population over age } 15 \text {, according to } \\
\text { External Circular Letter } 000058 \text { (2009) } \\
\text { of the Ministry of Social Protection. The } \\
\text { observed SS+ rate for the Colombian } \\
\text { population was then considered }\end{array}$ & $\begin{array}{l}\text { Population census, External Circular Letter } \\
000058 \text { (2009) of the Ministry of Social } \\
\text { Protection and External Circular Letter } 000055 \\
\text { (2016) of the Ministry of Health and Social } \\
\text { Protection (18) }\end{array}$ \\
\hline & Gap 1 & $\begin{array}{l}\text { Total number of undiagnosed PTB } \\
\text { patients }\end{array}$ & $\begin{array}{l}\text { This was estimated as the difference } \\
\text { between "Step 1" and "Step 2" }\end{array}$ & $\begin{array}{l}\text { Population census, External Circular Letter } \\
000058 \text { (2009) of the Ministry of Social } \\
\text { Protection and External Circular Letter } 000055 \\
\text { (2016) of the Ministry of Health and Social } \\
\text { Protection (18), database of the departmental } \\
\text { TB control program, and quarterly reports } \\
\text { from health service providers (HSPs) }\end{array}$ \\
\hline \multirow[t]{2}{*}{$\begin{array}{l}\text { Diagnosis and initiation of } \\
\text { treatment }\end{array}$} & Step 2 & $\begin{array}{l}\text { Total number of patients diagnosed } \\
\text { with PTB }\end{array}$ & $\begin{array}{l}\text { Total number of patients reported as PTB } \\
\text { cases in the indigenous population }\end{array}$ & $\begin{array}{l}\text { Departmental TB control program database, } \\
\text { quarterly reports from HSPs. Patients' } \\
\text { registered indigenous ethnicity was validated } \\
\text { using treatment reports }\end{array}$ \\
\hline & Step 3 & $\begin{array}{l}\text { Total number of patients who } \\
\text { initiated treatment }\end{array}$ & $\begin{array}{l}\text { Number of reported patients with } \\
\text { recorded initiation of treatment }\end{array}$ & $\begin{array}{l}\text { Departmental TB control program database } \\
\text { and quarterly reports from HSPs }\end{array}$ \\
\hline \multirow[t]{2}{*}{ Adherence to treatment } & Gap 3 & $\begin{array}{l}\text { Total number of patients whose } \\
\text { treatment failed, who died, or who } \\
\text { were lost to treatment }\end{array}$ & $\begin{array}{l}\text { Number of patients whose treatment } \\
\text { failed, who died, or who were lost to } \\
\text { treatment }\end{array}$ & $\begin{array}{l}\text { Departmental TB control program database } \\
\text { and quarterly reports from HSPs }\end{array}$ \\
\hline & Step 4 & $\begin{array}{l}\text { Total number of patients who } \\
\text { completed treatment }\end{array}$ & $\begin{array}{l}\text { Number of patients who were cured or } \\
\text { completed treatment }\end{array}$ & $\begin{array}{l}\text { Departmental TB control program database } \\
\text { and quarterly reports from HSPs }\end{array}$ \\
\hline \multirow[t]{2}{*}{ Post-treatment mortality } & Gap 4 & $\begin{array}{l}\text { Total number of patients who died } \\
\text { within } 18 \text { months after completion } \\
\text { of treatment }\end{array}$ & $\begin{array}{l}\text { Number of patients who died within } 18 \\
\text { months after completion of treatment }\end{array}$ & RUAF database \\
\hline & Step 5 & $\begin{array}{l}\text { Total number of patients who } \\
\text { completed treatment and were still } \\
\text { alive } 18 \text { months later }\end{array}$ & $\begin{array}{l}\text { This was estimated as the difference } \\
\text { between "Step 4" and "Gap 4" }\end{array}$ & $\begin{array}{l}\text { RUAF database (births and deaths module) } \\
\text { and departmental TB control program } \\
\text { database }\end{array}$ \\
\hline
\end{tabular}

Source: the authors.

Five percent of half the population over age 15 is a guideline for programmatic management of TB in Colombia, as established by the Ministry of Social Protection in External Circular Letter No. 000058 (2009). This guideline is important for estimating the target number of respiratory symptomatics who must be captured each year in territorial entities, districts, and municipalities. The source document does not mention a rationale for this form of estimation.

PTB: pulmonary tuberculosis; RS: respiratory symptomatic; RUAF (Single Register of Affiliates): births and deaths module.

each step and each gap in the care cascade. Microsoft Excel ${ }^{\circledR}$ and STATA $14^{\circledR}$ (StataCorp, College Station, TX, United States of America) were used for data analysis.

A thematic analysis was carried out as part of the qualitative component (22). Textual transcription of audio recordings was performed in Microsoft Word $^{\circledR}$. The transcriptions were then entered in Atlas.ti version $8^{\circledR}$ for coding and analysis. Program coordinators were encoded as "CP" and auxiliaries as "AP". The letter "I" was assigned to indigenous HSPs and "E" to public HSPs, followed by the letters "Ai" (high incidence) or "Bi" (low incidence), depending on conditions in the municipality. Finally, consecutive numbers were assigned to interviewees. The analysis followed the previously identified categories in the cascade (capture, detection, and treatment). The possibility of other categories was left open (23).

The methods were integrated through triangulation of quantitative and qualitative results (12). A comparison and contrast exercise were conducted to find possible explanations for each quantitatively identified gap, based on qualitative testimony.

The study was approved by the Research Ethics Committee of the National Faculty of Public Health of the University of Antioquia. It was exempted from review by the Ethics Review
Committee of the Pan American Health Organization (PAHOERC).

\section{RESULTS}

An estimated 202 patients with respiratory symptoms were expected to be positive. However, only $52.5 \%$ ( $n=106)$ were diagnosed by the health services (Table 2), representing a gap of $47.5 \%$ undiagnosed people (gap 1). All diagnosed patients initiated treatment, but the gap between initiation and completion of treatment (i.e., patients who started treatment but then failed, died, or were lost to follow-up) was 3.5\% (n=7). Finally, $49 \%$ of patients completed treatment and remained alive 18 months later (Figure 1 and Table 3).

The information from the qualitative component showed no substantial differences in the perceptions of individuals from different professions or different municipalities.

\section{Gap 1: Explanations for undiagnosed PTB cases}

Poor quality of samples and flawed smear techniques. Program coordinators reported that a significant number of samples 
examined in HSP labs are of saliva. Since most are smear samples processed in the field by auxiliaries, the technique used is not always the best, hindering the staining and reading process.

"Sometimes they bring it in a big lump and, as we know, sometimes the bug is further down and you can't see it. [The person] may be positive but the layer is so thick that the bacillus may be hidden; but they [the nursing auxiliaries] do not understand that; they think that having a big sample is good enough." CP_I_Bi_04

Failure to correctly identify RS. The interviews revealed that the pressure to meet targets has led health workers, especially activesearch nurses, to sample people who do not meet the definition of RS. Sometimes, in order to complete serial SS microscopy, inappropriate practices are followed, such as spreading a single sputum sample on two slides. Similarly, the conditions in which samples are transported do not guarantee their viability.

"... It is very difficult for the nursing auxiliaries to collect three samples, so they just collect two... from the second one we take two in order to have all three." AP_I_Bi_04

"... no, we don't have anything specific (to transport the samples). I use a bag and I carry it home or maybe you just carry it in your hand and that's it." AP_I_Bi_07

Limited access to diagnostic methods such as culture and molecular testing. Respondents say that sputum sample analysis is limited to SS microscopy, which is easy and affordable given the infrastructure of primary HSPs. Cultures are not usually used because the laboratories that produce them are located in the capital city. This is also the case with molecular testing. Furthermore, the administrative procedures for laboratory testing required by insurers and the total lack of specialized laboratories in the territories contribute to this problem, which increases the fragmentation of services.

"Users have to contact their health promoter or insurer in order to visit the city where the appointment has been made." CP_E_Ai_01

"For SS, yes, we have it here at the first level; for X-rays you have to go to (municipality 20 kilometers away); and for PPD (tuberculin test), to (a municipality 50 kilometers away)." CP_I_Bi_04

Limited training and high turnover of personnel in HSPs. Nursing auxiliaries say there are few ongoing TB training processes. In addition, staff turnover is high. Medical and nursing professionals avoid working in HSPs located in hard-to-reach municipalities or with public order problems. Turnover for technical personnel ranges from six months to two years, due to internal policies of the municipalities that administer indigenous HSPs.

"We have not received TB training per se. What we do is we read information on the internet, for example." AP_I_Bi_09

\section{Gap 3: Explanations for treatment failure, loss to follow-up, or death}

Barriers to supervision or self-administered treatment. The program coordinators say that when a person living in a rural
TABLE 2. Characteristics of reported cases of pulmonary tuberculosis in the indigenous population of Cauca, Colombia (2016-2017)

\begin{tabular}{|c|c|c|}
\hline \multirow[t]{2}{*}{ Characteristics } & \multicolumn{2}{|c|}{ Indigenous population } \\
\hline & $N=106$ & $\%$ \\
\hline \multicolumn{3}{|l|}{ Sex } \\
\hline Male & 60 & 56.6 \\
\hline Female & 46 & 43.4 \\
\hline Age at diagnosis (years) a & 41.5 & $(24-61)$ \\
\hline$\leq 15$ & 10 & 9.4 \\
\hline $16-35$ & 33 & 31.1 \\
\hline $36-55$ & 24 & 22.7 \\
\hline$\geq 56$ & 39 & 36.8 \\
\hline \multicolumn{3}{|l|}{ Reporting period } \\
\hline 2016 & 38 & 35.9 \\
\hline 2017 & 68 & 64.1 \\
\hline \multicolumn{3}{|l|}{ Municipality of origin } \\
\hline Caldono & 14 & 13.2 \\
\hline Toribio & 13 & 12.3 \\
\hline Santander de Quilichao & 10 & 9.4 \\
\hline Timbiquí & 10 & 9.4 \\
\hline Páez & 8 & 7.5 \\
\hline Corinto & 7 & 6.6 \\
\hline La Vega & 7 & 6.6 \\
\hline Jambaló & 5 & 4.7 \\
\hline Silvia & 5 & 4.7 \\
\hline Caloto & 4 & 3.8 \\
\hline Inzá & 4 & 3.8 \\
\hline Piendamó & 4 & 3.8 \\
\hline Other ${ }^{b}$ & 15 & 14.2 \\
\hline \multicolumn{3}{|l|}{ Indigenous peoples } \\
\hline Nasa & 75 & 70.8 \\
\hline Eperara Siapidara & 13 & 12.3 \\
\hline Yanacona & 9 & 8.5 \\
\hline Misak & 8 & 7.5 \\
\hline Inga & 1 & 0.9 \\
\hline \multicolumn{3}{|l|}{ Health care regimen } \\
\hline Subsidized & 101 & 95.3 \\
\hline Contributory & 3 & 2.8 \\
\hline Uninsured & 2 & 1.9 \\
\hline $\begin{array}{l}\text { Condition at entry to } \\
\text { program }\end{array}$ & & 90 \\
\hline New & 96 & 90.6 \\
\hline Re-entry after relapse & 10 & 9.4 \\
\hline HIV co-infection & 4 & 3.8 \\
\hline DST conducted & 3 & 2.8 \\
\hline Drug resistance detected & 1 & 0.9 \\
\hline \multicolumn{3}{|l|}{$\begin{array}{l}\text { Condition at time of leaving } \\
\text { program }\end{array}$} \\
\hline Cured & 75 & 70.8 \\
\hline Treatment completed & 24 & 22.7 \\
\hline Died during treatment & 5 & 4.7 \\
\hline Not evaluated & 1 & 0.9 \\
\hline Lost to follow-up & 1 & 0.9 \\
\hline
\end{tabular}

aMedian (interquartile range). Miranda, Morales, Piedmont, Popayán, and Sotará).

HIV: human immunodeficiency virus; DST: drug susceptibility testing.

Source: the authors, based on TB control program database. 
FIGURE 1. Care cascade for pulmonary tuberculosis in the indigenous population of Cauca, Colombia (2016-2017) 250

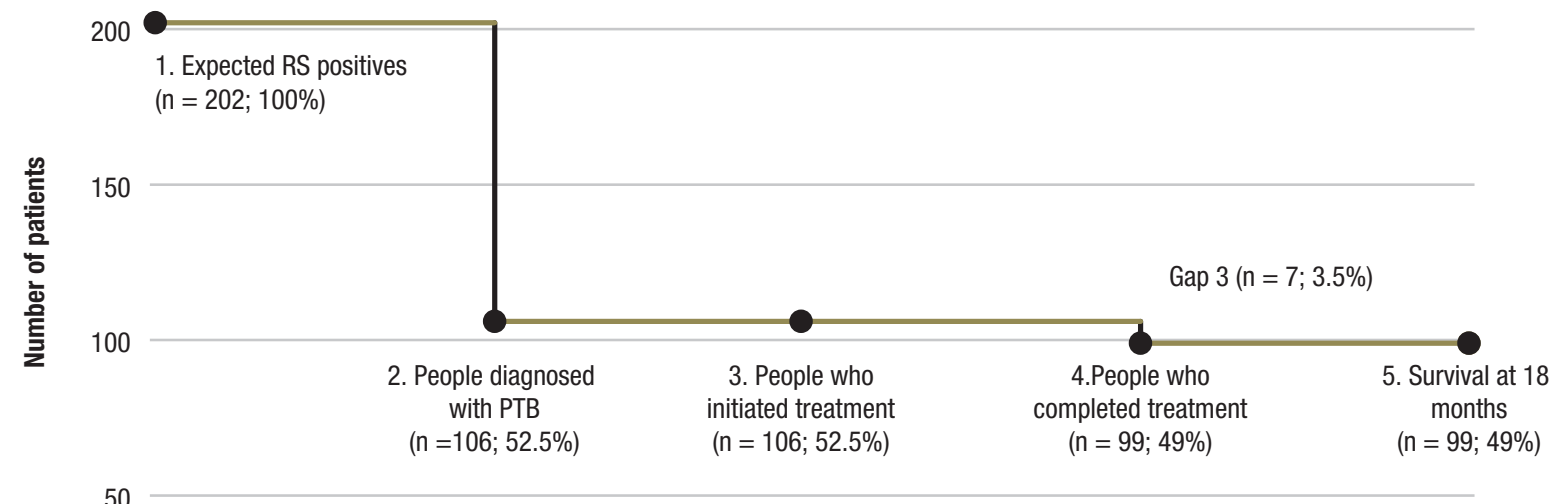

50

0

\section{Steps and gaps in the cascade}

Source: the authors, with data taken from: National Administrative Department of Statistics (DANE); database of the departmental TB control program; quarterly reports from HSPS (treatment sheets were used to validate the type of

indigenous population in patients registered as members of an indigenous/ethnic group); Single Affiliate Registration (RUAF) database (births and deaths module); and findings from the qualitative phase.
RS: respiratory symptomatic; PTB: pulmonary tuberculosis; HSP: health service provider.

TABLE 3. Calculations and limitations on the PTB care cascade in the indigenous population of Cauca, Colombia (2016-2017)

Steps and gaps

Step 1

Gap 1

Step 2

Gap 2

Step 3

Gap 3

Step 4

Gap 4

Step 5

Calculation

Assumption 1. Proportion of over-15s in the population projection for the department of Cauca for $2016=72.1 \%$

Assumption 2. Proportion of over-15s in the population projection for the department of Cauca for $2017=72.5 \%$

Assumption 3. Projected indigenous population in the Department of Cauca for $2016=344,922$

Assumption 4. Projected indigenous population in the Department of Cauca for $2017=287,295$

Assumption 5. Indigenous population over age 15 in $2016=$ Assumption $3 \times$ Assumption $1 / 100=248,668$

Assumption 6. Indigenous population over age 15 in $2017=$ Assumption $4 \times$ Assumption $2 / 100=208,288$

Assumption 7. 50\% of over-15s in indigenous population in 2016-2017 = Assumption $5+$ Assumption $6 \times 0.5=228,478$

Assumption $8.5 \%$ of over-15s in indigenous population in 2016-2017 = Assumption $7 \times 0.05=11,423$

Assumption 9. Total expected RS in the indigenous population of Cauca in Colombia in 2016-2017 $=11,423$

Assumption 10. Observed positivity rate for SS microscopy in Colombia in $2015=1.77 \%$

Total expected RS in the indigenous population of Cauca in Colombia in 2016-2017 = Assumption $9 \times$ Assumption $10 / 100=202$

Total undiagnosed PTB patients $=$ Step $1-$ Step $2=96$

Total number of PRI with PTB in 2016-2017 $=106$

Total number of patients diagnosed with PTB who did not start treatment in 2016-2017 = Step $2-$ Step $3=0$

Total number of PRI with PTB in 2016-2017 who started treatment $=106$

Assumption 1. Total number of PRI with PTB in 2016-2017 who started treatment and died during follow-up $=5$

Assumption 2. Total number of PRI with PTB in 2016-2017 who started treatment and were lost to follow-up $=1$

Assumption 3. Total number of PRI with PTB in 2016-2017 who started treatment and were not evaluated during follow-up, according to Cauca departmental TB control database $=1$

Total number of patients with treatment failure, death, or loss to follow-up = Assumption $1+$ Assumption $2+$ Assumption $3=7$

Total number of PRI with PTB in 2016-2017 who were cured or completed treatment $=99$

Assumption. Total number of PRI with PTB in 2016-2017 who started then completed treatment and died during the 18 months after completing the program $=0$

Total number of RIP with PRI in 2016-2017 who started then completed treatment and remained alive 18 months after completing the program = Step 4 - Gap $4=99$

Source: the authors.

Source: the authors.
RS: respiratory symptomatics; PRI: patients reported as indigenous; PTB: pulmonary tuberculosis.

area is diagnosed, treatment supervision is difficult. In this regard, community leaders, family members, or even patients themselves are trained to administer treatment.
"We gave him the [drugs for] treatment even though it was a huge risk because we gave him six months' worth. We made an agreement and I think he (the user) didn't take them, so he came 
back and tested positive... The cost of strictly supervised treatment is very high and assigning the nearest nurse auxiliary to go there every day would involve two hours of travel. The auxiliary has to walk every day, so it is exhausting." CP_E_Ai_09

Few support networks. Most key players agree that people with TB who live alone or do not have support from family or friends are more vulnerable and may lose motivation to continue their recovery process.

"... the previous year was a little complicated because the patient didn't want the family to do it and the family was not very close to him... the family did not live with him. He lived alone about three houses away from the family, but they didn't go to the hospital. A hospital auxiliary who lived nearby was in charge of taking him the medication every day." CP_E_Bi_02

High mobility of patients. Another explanation is the high mobility of people for different reasons, such as job searches, which makes it difficult for health personnel to follow up. To try to counteract this, local leaders often support sick residents with funds for commuting to follow-ups during treatment or with in-kind donations such as grains and other groceries.

\section{"... We lose users and we can't find them; they take off and we go around looking for them CP_E_Ai_09 \\ "... well, a difficult patient, actually. He was here for about two weeks, then he came back and left again, I think he went to Valle (another department). He received treatment there, then came back a couple of days ago. He's here again, so it's a little difficult." CP_E_Bi_02}

\section{DISCUSSION}

This is the first study in Colombia to analyze the TB care cascade in indigenous populations. This is relevant for local decision-making and provides evidence on this issue. The cascade assessment showed a $47.5 \%$ gap between expected smear-positive cases and the number of people actually diagnosed. Possible explanations included poor quality of samples, flawed smear techniques, poor identification of RS, limited access to diagnostic methods such as cultures and molecular tests, and limited training and high staff turnover in HSPs.

Most studies on the TB care cascade have looked at large populations, without focusing on ethnicity. The TB care cascade in the general population of India resulted in $43 \%$ one-year recurrence-free survival as the final step $(15,16)$. In South Africa, the TB care cascade achieved $53 \%$ and successful treatment was the final step (24). These findings are similar to those of this study.

The gaps in the cascade vary depending on the population studied. In India, Kenya and Uganda, the lack of TB diagnosis has been identified as the main gap in the cascade $(15,16,25)$. These findings are consistent with those of this study. In South Africa, a lack of successful treatment was identified as a significant gap in the care cascade (24), contrary to what was reported in this study, where the gap was minimal, and the explanations found did not appear to impact the outcome of the indicator. These differences in findings could be explained by contextual factors, the use of different diagnostic tests, and differences in the estimates made at each step in the cascade.
A study in India reported that $62 \%$ of indigenous physicians identified between two and five suspected TB cases per month. However, only $23 \%$ prescribed SS to diagnose the disease (26). A qualitative study in Peru reported low availability of diagnostic methods as one of the main problems in the Ashaninka indigenous community. Not all health centers in this community had the capacity to collect and transport samples to the reference laboratory in a timely manner (27). Another study found that more than $25 \%$ of sputum-smear microscopy in indigenous populations was for people asking for it as a job requirement. In addition, because technical staff were given mandatory monthly targets, their efforts focused on achieving those targets and they sampled asymptomatic people (28). This is consistent with this study's finding of flaws in the correct identification of RS in indigenous communities.

In indigenous communities in Colombia, an identified barrier to diagnosis and adequate treatment was the scarcity of forms of transportation and the difficulties involved in traveling to cities where HSPs are located, due to the lack of an efficient public transport system $(5,29)$. Similarly, health professionals working in rural Peru have reported limited access to diagnostic tools for TB in care facilities (30). This, together with our findings, confirms the limited access to TB diagnosis due to centralization in cities.

A study of the TB care cascade from the perspective of health workers in a hospital setting indicated that shortages of nurses have negative consequences on the quality of care (31). This suggests that difficulties facing health workers are greater in hard-to-reach primary care settings, such as in this study. In Mexico, indigenous community health workers address the health needs of their communities with both an allopathic and traditional understanding of medicine. They ensure comprehensive TB control in their communities, which are affected by high disease burdens, difficult physical access, public order issues, and inadequate health care infrastructure (32). Together with the findings of this study, all of above underline the need for HSPs to hire indigenous health workers and provide them with continuous training. This strategy has already been studied in indigenous communities in Brazil, where access to biomedical health resources is facilitated by bringing indigenous health actors into the state health system, while recognizing the importance of traditional medicine and other practices such as self-care (33).

The identified gaps may also reflect a lack of culturally appropriate TB control policies. In countries such as Australia, it has been shown that indigenous people have a low profile in TB control programs and public policies (34). As a result, it is necessary to jointly develop effective control strategies with the participation of indigenous communities, based on cultural and social processes in each population, while minimizing the vertical deployment of programmatic interventions.

The care cascade has two potential benefits: as an approach to quantifying TB outcomes and as a conceptual framework for examining the quality of health services at various stages of care. TB care cascades should be applied to high-risk populations in countries with a high disease burden (16). These epidemiological contexts are addressed in this study and have not been reported in the current literature. This study addresses the quality of the TB control program in the indigenous population of Cauca (Colombia), using a mixed research approach that allows for contextual analysis (35). 
In this study, there were some limitations in the construction of the cascade. Since the prevalence of PTB in the indigenous population in Colombia was unknown, it was not possible to estimate $95 \%$ confidence intervals, as proposed by Subbaraman et al. $(15,16)$. Therefore, the total number of expected positive respiratory symptomatics was calculated. To do this, reference was made to the program's specific guidelines for RS and the sputum smear positivity rate observed in Colombia (18). Also, the expected number of positive RS was adjusted based on the department's projected indigenous population, according to the latest census. Nevertheless, there are limitations in the data from secondary sources, since the TB control program does not discriminate RS based on indigenous status.

In conclusion, the findings of this study show a significant gap in TB detection, largely explained by poor quality of samples and flawed smear techniques, flaws in correct identification of respiratory symptomatics, limited access to diagnostic methods such as culture and molecular tests, and limited training and high turnover of personnel in health service providers. No gaps were found between diagnosed and treated patients, and the gap for completion of treatment was minimal. Further research is therefore needed to explain this situation.

To improve the TB control program in the indigenous population, the following is recommended: (i) strengthen continuous training for health personnel through the development of standardized content using tools such as information and communication technologies; (ii) explore the implementation of rapid diagnostic tests; (iii) consider hiring indigenous nursing auxiliaries for program management; and (iv) involve the indigenous community in education on TB prevention and control, employing knowledge dialogue for a more holistic approach.

Authors' contributions. JEPP and IRM were responsible for the concept and design of this study. They also analyzed and interpreted the data and wrote the manuscript. KYTH contributed to the concept and design, supported the fieldwork logistics, obtained secondary sources, and critically reviewed the manuscript. PTP and FP contributed to the concept and design and critically reviewed the manuscript. BLGS conducted semi-structured interviews, analyzed qualitative information, and critically reviewed the manuscript. All the authors read and approved the final manuscript.

\section{Conflict of Interest. None declared by the authors.}

Funding. This research was funded by the UNICEF/UNDP/ World Bank/WHO Special Program for Research and Training in Tropical Diseases (TDR), a program co-sponsored by the World Health Organization (WHO) as part of the call for proposals 'Embedding Research for the Sustainable Development Goals' initiative. This funding source has not influenced the collection, analysis, or interpretation of data.

Disclaimer. Authors hold sole responsibility for the views expressed in the manuscript, which may not necessarily reflect the opinion or policy of the RPSP/PAJPH and/or PAHO.

\section{REFERENCES}

1. World Health Organization. Global tuberculosis report 2019 [Internet]. Geneva; 2019 [cited 2019 Dec 26]. Available at: https://apps. who.int/iris/bitstream/handle/10665/329368/978924156571 4-eng.pdf?ua $=1$

2. Cormier M, Schwartzman K, N’Diaye DS, Boone CE, Dos Santos AM, Gaspar J, et al. Proximate determinants of tuberculosis in Indigenous peoples worldwide: a systematic review. Lancet Glob Health. 2019;7(1):e68-80.

3. Tollefson D, Bloss E, Fanning A, Redd JT, Barker K, McCray E. Burden of tuberculosis in indigenous peoples globally: a systematic review. Int J Tuberc Lung Dis. 2013;17(9):1139-50.

4. Tuberculosis in the Americas, 2018 [Internet]. Washington, D.C.: PAHO; 2018 [cited 2018 Oct 21]. Available at: http://iris.paho.org/ xmlui/handle/123456789/49510?show=full

5. Hernandez Sarmiento JM, Davila Osorio VL, Martinez Sanchez LM, Restrepo Serna L, Grajales Ospina DC, Toro Montoya AE, et al. Tuberculosis in indigenous communities of Antioquia, Colombia: epidemiology and beliefs. J Immigr Minor Health. 2013 Feb;15(1):10-6.

6. Bergonzoli G, Castellanos LG, Rodriguez R, Garcia LM. Determinants of tuberculosis in countries of Latin America and the Caribbean. Rev Panam Salud Publica. 2016;39(2):101-5.

7. Instituto Nacional de Salud. Informe del evento tuberculosis, Colombia, 2017 [Internet]. Instituto Nacional de Salud. Bogotá: INS; 2018 [cited 2018 Sep 28]. Available at: https:/ / www.ins.gov.co/buscador-eventos/Informesdeevento/Tuberculosis 2017.pdf

8. Gobernación del Cauca. Registros del programa departamental de tuberculosis. Popayán; 2017.

9. Ministerio de Salud y Protección Social. Plan estratégico hacia el fin de la tuberculosis, 2016-2025 [Internet]. Colombia; 2017 [cited 2018 Sep 28]. Available at: https://www.minsalud.gov.co/sites/rid/ Lists/BibliotecaDigital/RIDE/INEC/INTOR/Plan-estrategicofin-tuberculosis-colombia-2016-2025.pdf
10. Perlman DC, Jordan AE, Nash D. Conceptualizing Care Continua: Lessons from HIV, Hepatitis C Virus, Tuberculosis and Implications for the Development of Improved Care and Prevention Continua. Front public Health. 2016;4:296

11. World Health Organization. Implementation research toolkit [Internet]. WHO, editor. Geneva: WHO; 2014 [cited 2018 Oct 26]. Available at: https://apps.who.int/iris/bitstream/ handle/10665/110523/9789241506960_Workbook_eng.pdf?sequence $=3 \&$ is Allowed $=y$

12. Creswell J, Plano V. Designing and conducting mixed methods research. 2nd ed. SAGE, editor. Washington DC: SAGE; 2011.

13. Teddlie C, Yu F. Mixed methods sampling: A typology with examples. J Mix Methods Res. 2007;1(1):77-100.

14. Ulin P, Robinson E, Tolley E. Investigación aplicada en salud pública: métodos cualitativos. Washington DC: OPS; 2006.

15. Subbaraman R, Nathavitharana RR, Satyanarayana S, Pai M, Thomas BE, Chadha VK, et al. The tuberculosis cascade of care in India's public sector: A systematic review and meta-analysis. PLoS Med. 2016;13(10):e1002149.

16. Subbaraman R, Nathavitharana RR, Mayer KH, Satyanarayana S, Chadha VK, Arinaminpathy N, et al. Constructing care cascades for active tuberculosis: A strategy for program monitoring and identifying gaps in quality of care. PLOS Med. 2019;16(2):e1002754.

17. Del Portillo-Mustieles EC, Laniado-Laborín R. Active case fin ding of pulmonary tuberculosis through screening of respiratory symptomatics using sputum microscopy: is it time to change the paradigm? Tuberc Res Treat. 2013;2013:312824.

18. Ministerio de Salud y Protección Social. Circular externa No. 000055 de 2016 [Internet]. Colombia; 2016. Available at: https:/ /www.minsalud.gov.co/sites/rid/Lists/BibliotecaDigital/RIDE/DE/ DIJ/ circular-externa-55-de-2016.pdf

19. Daza Arana JE, Cubides Munévar AM, Lozada Ramos H. Prevalencia de sintomáticos respiratorios y factores relacionados en dos 
territorios vulnerables de Santiago de Cali. Hacia la Promoción la Salud. 2016;21:63-76.

20. World Health Organization. Definitions and reporting fra mework for tuberculosis-2013 revision [Internet]. Geneva: WHO; 2013 [cited 2019 Dec 26]. Available at: https://apps.who. int/iris/bitstream/handle/10665/79199/9789241505345_eng. pdf? sequence $=1$ \&isAllowed $=y$

21. Edwards R, Holland J. What is qualitative interviewing? London: Bloomsbury Publishing; 2013.

22. Fereday J, Muir-cochrane E. Demonstrating Rigor Using Thematic Analysis : A Hybrid Approach of Inductive and Deductive Coding and Theme Development. Int J Qual methods. 2006;5(1):80-92.

23. Hernández R, Fernández C, Baptista P. Metodología de la investigación. 5th ed. México: McGrawHill; 2010.

24. Naidoo P, Theron G, Rangaka MX, Chihota VN, Vaughan L, Brey ZO, et al. The South African tuberculosis care cascade: Estimated losses and methodological challenges. J Infect Dis. 2017;216(suppl_7):S702-13.

25. Mwangwa F, Chamie G, Kwarisiima D, Ayieko J, Owaraganise A, Ruel TD, et al. Gaps in the Child Tuberculosis Care Cascade in 32 Rural Communities in Uganda and Kenya. J Clin Tuberc other Mycobact Dis. 2017;9:24-9.

26. Anandhi CL, Nagaraj VK, Kumar R. Knowledge and practice pattern of non-allopathic indigenous medical practitioners regarding tuberculosis in a rural area of India. Int J Tuberc Lung Dis. 2002;6(6):553-5.

27. Gianella C, Ugarte-Gil C, Caro G, Aylas R, Castro C, Lema C. TB in vulnerable populations: The case of an indigenous community in the Peruvian Amazon. Health Hum Rights. 2016;18(1):55-68.

28. Gianella C, Pesantes MA, Ugarte-Gil C, Moore DAJ, Lema C. Vulnerable populations and the right to health: lessons from the Peruvian Amazon around tuberculosis control. Int J Equity Health. 2019;18(1):28.

29. Sánchez Lerma L, Carrillo Franco J, Ochoa Bernal Y, Pérez-Gutiérrez N. Aproximación a la situación de la Tuberculosis pulmonar en comunidades indígenas del municipio Puerto Gaitán, Meta, Colombia. Rev Habanera Ciencias Médicas. 2018;17(3):462-80.
30. Anticona Huaynate CF, Pajuelo Travezano MJ, Correa M, Mayta Malpartida H, Oberhelman R, Murphy LL, et al. Diagnostics barriers and innovations in rural areas: insights from junior medical doctors on the frontlines of rural care in Peru. BMC Health Serv Res. 2015; $15: 454$

31. Lisboa M, Fronteira I, Mason PH, Martins M do RO. National TB program shortages as potential factor for poor-quality TB care cascade: Healthcare workers' perspective from Beira, Mozambique. PLoS One. 2020;15(2):e0228927-e0228927.

32. Herce ME, Chapman JA, Castro A, Garcia-Salyano G, Khoshnood $\mathrm{K}$. A role for community health promoters in tuberculosis control in the state of Chiapas, Mexico. J Community Health. 2010;35(2): 182-9.

33. Pontes AL, Rego S, Garnelo L, Pontes AL, Rego S, Garnelo L. La actuación de agentes indígenas de salud en la región de Alto Rio Negro, Brasil: relaciones entre autoatención y biomedicina. Desacatos [Internet]. 2018 [cited 2020 Sep 13];(58):84-103. Available at: http://www.scielo.org.mx/scielo.php?script=sci_arttext\&pid=S1607-050X2018000300084\&lng=es\&nrm=iso\&tlng=es

34. Devlin S, MacLaren D, Massey PD, Widders R, Judd JA. The missing voices of Indigenous Australians in the social, cultural and historical experiences of tuberculosis: a systematic and integrative review. BMJ Glob Health. [Internet]. 2019;4(6):e001794. Disponible en: http://gh.bmj.com/content/4/6/e001794.abstract

35. McDowell A, Engel N, Daftary A. In the eye of the multiple beholders: Qualitative research perspectives on studying and encouraging quality of TB care in India. J Clin Tuberc Other Mycobact Dis. 2019;16:100111.

Manuscript (original in Spanish) received on 18 June 2020. Revised version accepted for publication on 15 September 2020. 


\section{Cascada de atención de la tuberculosis para la población indígena en Colombia: una investigación operativa}

RESUMEN Objetivo. Construir y evaluar la cascada de atención de la tuberculosis pulmonar en la población indígena del departamento del Cauca (Colombia) e identificar las brechas existentes.

Métodos. Metodología mixta con diseño secuencial explicativo. En la primera fase se evaluó la cascada de atención de la tuberculosis pulmonar para la población indígena del Cauca. Se obtuvieron datos de fuentes secundarias y se incluyeron todos los casos diagnosticados entre el 1 de enero del 2016 y el 31 de diciembre de 2017. En la segunda fase, se aplicaron entrevistas semiestructuradas a nueve coordinadores de programa y 11 auxiliares de enfermería para explicar las brechas identificadas. Se estimaron los valores absolutos y porcentuales en cada uno de los pasos y las brechas de la cascada de atención. Se triangularon los resultados cuantitativos y cualitativos.

Resultados. Durante 2016 y 2017 se estimaron 202 sintomáticos respiratorios esperados positivos y se notificaron 106 casos de tuberculosis pulmonar en la población indígena del departamento del Cauca. Se encontró una brecha de 47,5\% para el diagnóstico, ya que solo 52,5\% de los sujetos recibieron el diagnóstico en los servicios de salud. Las explicaciones a esta brecha fueron la mala calidad de muestras y fallas en la técnica del extendido, fallas en la correcta identificación del sintomático respiratorio, acceso limitado a métodos diagnósticos como cultivo y pruebas moleculares, así como capacitación escasa y rotación alta de personal al interior de las instituciones prestadoras de servicios de salud.

Conclusiones. Las acciones del programa de control de tuberculosis deben enfocarse en reducir la brecha de detección de casos en la población indígena.

Palabras clave Tuberculosis; población indígena; servicios de salud del indígena; calidad, acceso y evaluación de la atención de salud; Colombia.

\section{Cascata de atenção da tuberculose para os povos indígenas na Colômbia: pesquisa operacional}

RESUMO Objetivo. Elaborar e avaliar a cascata de atenção da tuberculose pulmonar na população indígena do Departamento de Cauca (Colômbia) e identificar as lacunas existentes.

Métodos. Metodologia mista com desenho sequencial explicativo. Na primeira fase, avaliamos a cascata de atenção da tuberculose pulmonar para a população indígena de Cauca. Os dados foram obtidos de fontes secundárias, incluindo todos os casos diagnosticados entre 1 de janeiro de 2016 e 31 de dezembro de 2017. Na segunda fase, realizamos entrevistas semiestruturadas com nove coordenadores do programa e 11 auxiliares de enfermagem para explicar as lacunas identificadas. Estimamos os valores absolutos e percentuais em cada uma das etapas e as lacunas na cascata de atenção. Os resultados quantitativos e qualitativos foram triangulados.

Resultados. Nos anos de 2016 e 2017, foi estimada a ocorrência de 202 casos com sintomas respiratórios com diagnóstico esperado positivo; no entanto, os serviços de saúde só diagnosticaram e notificaram 106 casos de tuberculose pulmonar na população indígena do Departamento de Cauca. Portanto, identificamos uma lacuna diagnóstica de 47,5\%, já que apenas 52,5\% dos casos receberam um diagnóstico nos serviços de saúde. As explicações para esta lacuna foram a má qualidade das amostras e falhas na técnica de esfregaço, falhas na identificação correta dos sintomas respiratórios, acesso limitado aos métodos de diagnóstico, tais como cultura e testes moleculares, bem como capacitação deficiente e alta rotatividade de pessoal nas instituições de saúde.

Conclusões. As ações do programa de controle da tuberculose devem se concentrar em reduzir a lacuna na detecção de casos na população indígena.

Palavras-chave Tuberculose; população indígena; serviços de saúde do indígena; qualidade, acesso e avaliação da assistência à saúde; Colômbia. 